\title{
MANAGEMENT, TREATMENT AND DISPOSAL OF SLUDGE PRODUCED FROM WATER TREATMENT PLANTS
}

\author{
Moustafa Abd Elmoniem Ashmawy ${ }^{1}$ \\ ${ }^{1}$ Assistant Professor of Sanitary Engineering, Civil Engineering Department, Faculty of Engineering - Mataria, \\ Helwan University, Cairo
}

\begin{abstract}
The dewatering of suspensions collected in the water treatment plants is known as water sludge is becoming a critical issue in Egypt now a day as treatment of such sludge has become a must before discharging into receiving water bodies. In this research the quality of sludge produced from the different water treatment units such as clarifiers and filter wash water was analyzed. Experiments were conducted on various clarification processes including clarification by traditional clarifiers in circular and rectangular arrangement and pulsator clarifiers. Several parameters were analyzed to assess the sludge quality treatment requirements. Analyses showed that the filter wash water is recyclable water that can be safely disposed of in water streams or to be recycled back to the treatment plants. Sludge from different clarifiers included a high concentration of residual Aluminum that required further treatment. Application of Microfiltration and Ultrafiltration membranes in dead end mode for treatment of sludge from clarifiers proved high capability in removing the hazardous parameters and can be recommended for further treatment of the sludge.
\end{abstract}

Keywords: Water Treatment, sludge, suspended solids, alum sulfate

\section{INTRODUCTION}

Egypt is facing great challenge dealing with sludge water produced from the existing water treatment plants. Formerly, wastes from water treatment plants were returned to their original source or discharged to nearby receiving water bodies. Egyptian Laws and regulations now consider waste discharged directly from water treatment plants to receiving water bodies as a hazardous pollutant and hence different types of wastes has to be treated to an acceptable level prior to their release into the environment, and water treatment plant wastes are no exception.

Much more than the development of alternative disposal options is the need to dewater suspensions to high solids, usually to a dry cake, prior to transport. Dewatering techniques such as thickening followed by either filtration or centrifugation are the methods of choice, the difficulty is often the range of suspensions produced in the water industry and the number of options available.[1]

The use of water treatment sludge in various industrial and commercial manufacturing processes has also been reported in UK, USA, Taiwan and other parts of the world as a re-use process to avoid the direct disposal. Successful pilot and full-scale trials have been undertaken in brick manufacture, cement manufacture, commercial land application. The mineralogical composition of the "water treatment sludge" is particularly close to that of clay and shale. This fact encourages the use of water treatment sludge in brick manufacture where sludge was incorporated with some of the agricultural and industrial wastes, such as rice husk ash (RHA) and silica fume (SF) were it was proven possible.[2]
Sludge properties has been always a matter of discussion, HanemAwab et al.,[3] investigated water treatment sludge to determine its physical and chemical properties. Sludge was obtained from the Semanggar Water Treatment Plant, Kota Tinggi, and Johore at Malaysia. Bulk density, particle density, porosity, surface area, particle size, moisture content, ash content, chemical composition, leachability of heavy metals, $\mathrm{pH}$ and the total organic carbon (TOC) were determined and a clear classification the sludge was reached.

It should be noted that most of the water treatment plants in Egypt discharges the sludge back to the river Nile and the surface water streams without treatment which leads to accumulative rise of aluminum concentrations in water, aquatic organisms, and human bodies, consequently stringent standards of effluent discharge are coming into effect, and thus proper management of the sludge becomes a must. [4],[5]

The scope of this study is to conduct a review on water treatment plant wastes with respect to sludge characteristics definition. Moreover, a deep sludge management steps towards volume reduction of backwash water and in-plant recycling of wash water will be under discussion.

It is of a high importance to mention that for plants currently having sludge treatment facilities or for those under design, cost and area reduction for sludge treatment is of high value especially with the limited available areas within all plants in the narrow Egyptian Nile valley of a real high population density. 


\section{MATERIALS AND METHODS}

To assess the water sludge characteristics, Gezert Al Dahab water treatment plant, located directly to the Nile at Giza, Cairo Egypt was selected as a typical representative case for the problem defined.

As the plant is located directly on the Nile bank, it has a very limited area and has seen already several extensions. The original capacity of the plant was $68000 \mathrm{~m}^{3} /$ day and the final capacity reached up to $453000 \mathrm{~m}^{3} /$ day. Three different types of flocculation, sedimentation and filtration are applied. The first phase of the plant consisted of typical rectangular baffled tanks for addition of chemicals and coagulation followed by typical rectangular tanks for longitudinal gravity settling as a sedimentation tank. The first phase constructed at the early seventies of the last decade has also accommodated rapid gravity filters equipped with backwash pumps of a capacity of five times the filtration rate as per the international practice.

On the other hand, the first extension for this plant was of the same a capacity of $200000 \mathrm{~m} 3 /$ day and applied the pulsators for clarification and sedimentation process followed by a similar rapid gravity filtration and back wash rate, while the second extension applied the lamella plates in rectangular tanks to enhance sedimentation with the same filtration and back wash theme. The above two stages shared the same raw water intake, raw water pumps, treated water pumps and sludge disposal pipe while the third extension of the plant constructed in 2010 with a capacity of $150000 \mathrm{~m} 3 /$ day can be considered as a complete individual plant as there are no common facilities between this extension and the previous once.

This last extension applied pulsator clarifiers followed by rapid gravity filters with back wash pumps matching with the same criteria of five times the filtration rate. The sludge produced from this plant is also directed to the same discharge point of the original plant. It should be noted that sludge produced from clarifiers and filters are collected separately and directly disposed of re use or return into any of the plant phases. As typical practice in other water treatment plants in Egypt, sludge is directly discharged back to the river Nile without treatment.

The coagulant aid used for enhancement of sedimentation at Gezert Al Dahab plant is the Alum Sulfate. The plant is routinely supplied by Alum Sulfate solution in concentration of $25 \%$ and then diluted within the plant to the desired required concentration. The applied dose of coagulant is determined daily by the use of jar test in the plant laboratory and it varies seasonally according to the Nile water quality at the plant intake and according to the flood compositions reaching to this area.

To achieve the study goals, work plan has been set to collect all available data about the sludge produced from the plant in terms of quality and characteristics to examine how much sludge production can be reduced by recirculating sludge from backwash water into the treatment units. This was followed by a field study using a pilot plant from Microfiltration/ Ultrafiltration membrane for treatment of the remaining sludge. Fig.(1) represents the current status of treatment lines at Gezeret Al Dahab WTP and samples locations.

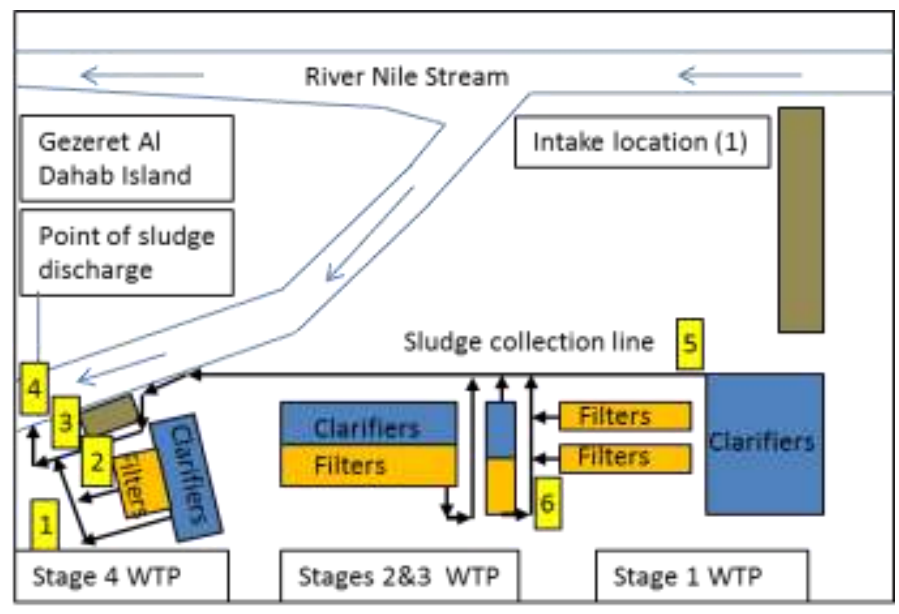

Fig.-1: Current situation of sludge collection - disposal \& samples locations

\section{WORK PROGRAM}

The following table shows the program of collecting samples from the different locations of the plant and the composition of each sample. Numbering of the samples was according to the sequence of collection taking into consideration the plant operation system and the interval of the filters washing process at the collection time.

Table -1: Samples locations and description

\begin{tabular}{|l|l|l|}
\hline Sample & Location & Description \\
\hline 1 & $\begin{array}{l}\text { Clarifier } \\
\text { sludge }\end{array}$ & $\begin{array}{l}\text { Sludge produced from pulsator } \\
\text { clarifiers every four hours }\end{array}$ \\
\hline 2 & Mixed sludge & $\begin{array}{l}\text { Mixture of sludge from } \\
\text { pulsator clarifiers and filter } \\
\text { wash water }\end{array}$ \\
\hline 3 & Filters outlet & $\begin{array}{l}\text { Wash Water from the filter } \\
\text { house after pulsator clarifiers }\end{array}$ \\
\hline 4 & $\begin{array}{l}\text { Mixed sludge } \\
\text { of the plant at } \\
\text { disposal } \\
\text { point }\end{array}$ & $\begin{array}{l}\text { Mixture from pulsator sludge- } \\
\text { clarifiers sludge and filter } \\
\text { wash water }\end{array}$ \\
\hline 5 & $\begin{array}{l}\text { Clarifier } \\
\text { sludge }\end{array}$ & $\begin{array}{l}\text { Sludge produced from } \\
\text { rectangular clarifiers }\end{array}$ \\
\hline 6 & Filter Outlets & $\begin{array}{l}\text { Wash Water from the filter } \\
\text { house after rectangular } \\
\text { clarifiers }\end{array}$ \\
\hline
\end{tabular}

Typical values for the raw water characteristics are shown in Table (2) where the Nile water parameters at the plant intake in comparison to the Nile water parameters at the point of sludge disposal collected from the main stream after mixing are shown where the impact of discharge of un treated sludge produced from the treatment plant to the river Nile at the downstream can be recognized with higher concentrations of residual Aluminum and Sulfates. 
Table -2: Nile water quality upstream the plant intake and at the sludge disposal point

\begin{tabular}{|l|l|l|l|}
\hline Parameter & Unit & $\begin{array}{l}\text { Upstream } \\
\text { the plant }\end{array}$ & $\begin{array}{l}\text { Downstream } \\
\text { the plant }\end{array}$ \\
\hline Temp & $\mathrm{C}^{\mathrm{O}}$ & 15.1 & 15.9 \\
\hline Turbidity & $\mathrm{NTU}$ & 7.2 & 7.6 \\
\hline Conductivity & $\mathrm{s} / \mathrm{cm}$ & 483 & 516 \\
\hline Ammonia $\left(\mathrm{NH}_{3}\right)$ & $\mathrm{mg} / \mathrm{l}$ & 0.32 & 0.08 \\
\hline Nitrite $\left(\mathrm{NO}_{2}\right)$ & $\mathrm{mg} / \mathrm{l}$ & 0.056 & 0.05 \\
\hline Nitrates $\left(\mathrm{NO}_{3}\right)$ & $\mathrm{mg} / \mathrm{l}$ & 0.24 & 0.18 \\
\hline T.Alkalinity $\mathrm{CaCo}_{3}$ & $\mathrm{mg} / \mathrm{l}$ & 162 & 138 \\
\hline Chlorides $(\mathrm{Cl})$ & $\mathrm{mg} / \mathrm{l}$ & 38 & 46 \\
\hline Sulfates $\left(\mathrm{SO}_{4}\right)$ & $\mathrm{mg} / \mathrm{l}$ & 37.4 & 60.4 \\
\hline Dissolved $\mathrm{Oxygen}_{1}$ Aluminum & $\mathrm{mg} / \mathrm{l}$ & 8.3 & 3.5 \\
\hline CO & $\mathrm{mg} / \mathrm{l}$ & 1 & 8 \\
\hline $\begin{array}{l}\text { Residual } \\
(\mathrm{AL})\end{array}$ & & 0.16 & 0.25 \\
\hline Algae count & $\mathrm{Unit} / \mathrm{ml}$ & 14500 & 400 \\
\hline
\end{tabular}

\section{RESULTS AND DISCUSSION}

According to the study program, analyses was carried to assess the sludge quality produced from the three water treatment streams with their relevant flocculation and sedimentation process, the traditional rectangular sedimentation tank, the circular clari-floculator tank and the pulsator clarifier. Results shown in Tables (2),(3) represents the routine analyses carried out by the operating company (Giza Company for Water \& Wastewater), for a mixture of clarifier sludge and filter wash water, while Tables (4),(5)\&(6) illustrate the additional analyses carried out during the research period at the National Center for Researches (NCR), Egypt at to study the different parameters required to assess the hazardous effect of the produced sludge on the surrounding environment in comparison with the local regulation of the effluent disposal stated by the Egyptian environmental laws.

Table -3: Results of the regular analyses carried out by the operator for the final mixture of sludge produced from the

plant.

\begin{tabular}{|c|c|c|c|c|c|c|c|c|}
\hline \multirow[t]{2}{*}{ Parameter } & \multirow{2}{*}{ Unit } & \multicolumn{7}{|c|}{ Results } \\
\hline & & Feb. & Mar. & April & May & June & July & Aug. \\
\hline Turbidity & NTU & 10.6 & 6.3 & 7.8 & 7.3 & 9.4 & 7.7 & 6.3 \\
\hline$\overline{\mathrm{PH}}$ & & 7.9 & 8 & 7.9 & 7.9 & 7.9 & 8 & 7.9 \\
\hline $\begin{array}{l}\text { Dissolved } \\
\text { Salts }\end{array}$ & $\mathrm{mg} / \mathrm{l}$ & 294 & 288 & 289 & 288 & 283 & 281 & 280 \\
\hline $\begin{array}{l}\text { Suspended } \\
\text { Solids }\end{array}$ & $\mathrm{mg} / \mathrm{l}$ & 890 & 800 & 810 & 830 & 800 & 795 & 810 \\
\hline Ammonia & $\mathrm{mg} / \mathrm{l}$ & 0.5 & 0.3 & 0.6 & 0.17 & 0.4 & 0.25 & 0.4 \\
\hline Iron & $\mathrm{mg} / \mathrm{l}$ & 0.23 & 0.17 & 0.15 & 0.13 & 0.4 & 0.26 & 0.5 \\
\hline So4 & $\mathrm{mg} / \mathrm{l}$ & 35.2 & 37 & 30 & 26 & ----- & ----- & ----- \\
\hline $\mathrm{AL}$ & $\mathrm{mg} / \mathrm{l}$ & 0.17 & 0.25 & 0.3 & ----- & ----- & ----- & ----- \\
\hline Alkalinity & & 150 & 148 & 146 & 146 & 148 & 142 & 150 \\
\hline $\mathrm{Mg}$ & $\mathrm{mg} / \mathrm{l}$ & 15.36 & 13.92 & 14.1 & -- & ----- & ---- & 15.6 \\
\hline \begin{tabular}{|l} 
Colony \\
Count
\end{tabular} & $\begin{array}{l}\mathrm{U} / 100 \\
\mathrm{ml}\end{array}$ & non & non & non & non & Non & non & Non \\
\hline $\begin{array}{l}\text { Residual } \\
\mathrm{Cl}\end{array}$ & $\mathrm{mg} / \mathrm{l}$ & 0.6 & 0.5 & 0.6 & 0.6 & 0.4 & 0.4 & 0.4 \\
\hline
\end{tabular}

Table -4: Toxicity characteristic leaching procedure (TCLP) regulatory levels (clarifier sludge)

\begin{tabular}{|l|l|l|l|}
\hline Metals & $\begin{array}{l}\text { TCLP Regulatory } \\
\text { Level, mg/L }\end{array}$ & $\begin{array}{l}\text { EPA Hazardous } \\
\text { Waste Number }\end{array}$ & $\begin{array}{l}\text { Result } \\
\mathrm{mg} / \mathrm{L}\end{array}$ \\
\hline Arsenic & 5.0 & D004 & 0.066 \\
\hline Aluminum & --- & --- & 1200.000 \\
\hline Barium & 100.0 & D005 & 0.056 \\
\hline Cadmium & 1.0 & D006 & $<0.01$ \\
\hline Chromium & 5.0 & D007 & 0.090 \\
\hline Lead & 5.0 & D008 & $<0.01$ \\
\hline Mercury & 0.2 & D009 & $<0.005$ \\
\hline Selenium & 1.0 & D010 & 2.040 \\
\hline Silver & 5.0 & D011 & $<0.01$ \\
\hline
\end{tabular}

Alum Sulfate was used as a coagulant and concentrations applied during the study period ranged from 28 to $32 \mathrm{mg} / \mathrm{l}$ based on the daily and seasonally Jar test results.

As the samples were very light in concentration to carry physicochemical analyses, they were left for settling and concentration for one hour before the concentrate was taken to conduct the analyses. Tables (5),(6) represent the results of the different parameters before and after concentration in comparison with the allowable limits by the Egyptian regulations mentioned as Decree No.48 for the year 1982 .

Table -5: Physico-Chemical analysis for samples before stilling

\begin{tabular}{|c|c|c|c|c|c|c|c|c|}
\hline \multirow[t]{2}{*}{ Parameter } & \multirow[t]{2}{*}{ Unit } & \multicolumn{6}{|c|}{ Sample No. } & \multirow{2}{*}{$\begin{array}{l}\text { Decree } \\
-48(1982)\end{array}$} \\
\hline & & 1 & 2 & 3 & 4 & 5 & 6 & \\
\hline Color & \begin{tabular}{|l} 
Co/PT \\
Unit
\end{tabular} & 1 & 1 & 1 & 1 & 1 & 1 & 100 \\
\hline Total Residue & $\mathrm{mg} / \mathrm{L}$ & 396 & 503 & 300 & 348 & 331 & 290 & 500 \\
\hline $\mathrm{pH}$ & & 8.4 & 8.7 & 8.5 & 8.6 & 8.6 & 8.6 & $7-8.5$ \\
\hline B.O.D & $\mathrm{mg} / \mathrm{L}$ & 1.7 & 2.4 & 2.8 & 2.5 & 2.3 & 2.4 & 6 \\
\hline C.O.D & $\mathrm{mg} / \mathrm{L}$ & 35 & 46 & 15 & 27 & 33 & 17 & 10 \\
\hline Organic Nitrogen & $\mathrm{mg} / \mathrm{L}$ & 3.9 & 5 & 2.9 & 2.8 & 2.2 & 2.2 & 1 \\
\hline Ammonia(NH3) & $\mathrm{mg} / \mathrm{L}$ & 0.25 & 0.0 & 0.0 & 0.1 & 0.15 & 0.0 & 0.5 \\
\hline $\begin{array}{l}\text { Total Alkalinity } \\
\text { (as } \mathrm{CaCO} 3 \text { ) }\end{array}$ & $\mathrm{mg} / \mathrm{L}$ & 120 & 114 & 138 & 116 & 118 & 118 & 150 \\
\hline Sulfate (So4) & $\mathrm{mg} / \mathrm{L}$ & 50.2 & 54.4 & 34.5 & 46.2 & 43.2 & 54.3 & 200 \\
\hline Iron & $\mathrm{mg} / \mathrm{L}$ & 0.5 & 0.7 & 0.5 & 0.5 & 0.3 & 0.1 & 1 \\
\hline Manganese & $\mathrm{mg} / \mathrm{L}$ & 0.2 & 0.18 & 0.18 & 0.11 & 0.13 & 0.11 & 0.5 \\
\hline Nitrate( NO3) & $\mathrm{mg} / \mathrm{L}$ & 0.25 & 0.23 & 0.23 & 0.3 & 0.28 & 0.2 & 45 \\
\hline Fluoride & $\mathrm{mg} / \mathrm{L}$ & 0.45 & 0.44 & 0.4 & 0.43 & 0.48 & 0.43 & 0.5 \\
\hline \begin{tabular}{|l|} 
Residual \\
Aluminum
\end{tabular} & $\mathrm{mg} / \mathrm{L}$ & 0.34 & 0.3 & 0.35 & 0.38 & 0.34 & 0.39 & 0.2 \\
\hline
\end{tabular}


It could be seen from table (5) results that several parameters of the different sludge sources are matching with the local regulation for disposal to open streams stated at the Egyptian environmental law known as Decree No.48/1992 and does not represent a source of hazard or contamination to the receiving stream. On the other hand, results of the COD, organic nitrogen and residual aluminum exceeded the allowable limits. Samples were left for one hour to settle and the concentrate was collected for analyses, where results are shown in Table (6). Additional parameters such as cadmium, lead, fluoride, mercury, Chromium and iron were also measured and recorded.

Results showed that there was a clear difference between the clarifier sludge and the filter wash water sludge. Samples No.(3),(6) representing sludge from filter wash water were much less in concentration than the clarifier sludge and the mixture.

Table -6: Physico-Chemical analysis for samples after stilling for one hour

\begin{tabular}{|c|c|c|c|c|c|c|c|c|}
\hline \multirow[t]{2}{*}{ Parameter } & \multirow[t]{2}{*}{ Unit } & \multicolumn{6}{|c|}{ Sample No. } & \multirow{2}{*}{$\begin{array}{l}\text { Decree } \\
48 \\
(1982)\end{array}$} \\
\hline & & 1 & 2 & 3 & 4 & 5 & 6 & \\
\hline Color & $\begin{array}{l}\mathrm{Co} / \mathrm{PT} \\
\text { Unit } \\
\end{array}$ & 0 & 0 & 0 & 0 & 0 & 0 & 100 \\
\hline Total Residue & $\mathrm{mg} / \mathrm{L}$ & 241 & 257 & 248 & 182 & 229 & 238 & 500 \\
\hline $\mathrm{pH}$ & & 8.2 & 7.9 & 8 & 8.1 & 8.2 & 8.2 & $7-8.5$ \\
\hline B.O.D & $\mathrm{mg} / \mathrm{L}$ & 1.8 & 1.4 & 2.1 & 1.5 & 1.6 & 1.4 & 6 \\
\hline C.O.D & $\mathrm{mg} / \mathrm{L}$ & 13 & 13.5 & 10 & 13 & 16 & 6 & 10 \\
\hline $\begin{array}{l}\text { Organic } \\
\text { Nitrogen }\end{array}$ & $\mathrm{mg} / \mathrm{L}$ & 2.2 & 4.9 & 3.5 & 3.7 & 4.7 & 3.4 & 1 \\
\hline Ammonia $\left(\mathrm{NH}_{3}\right)$ & $\mathrm{mg} / \mathrm{L}$ & 0.2 & 0.1 & 0.09 & 0.8 & 0.1 & 0.1 & 0.5 \\
\hline $\begin{array}{l}\text { Total Alkalinity } \\
\text { (as } \mathrm{CaCO} 3 \text { ) }\end{array}$ & $\mathrm{mg} / \mathrm{L}$ & 120 & 114 & 138 & 116 & 118 & 118 & 150 \\
\hline Sulfate $\left(\mathrm{SO}_{4}\right)$ & $\mathrm{mg} / \mathrm{L}$ & $\begin{array}{l}50 . \\
2\end{array}$ & 54.4 & 34.5 & 46.2 & 43.2 & 54.3 & 200 \\
\hline Iron & $\mathrm{mg} / \mathrm{L}$ & $\begin{array}{l}0.0 \\
1 \\
\end{array}$ & 0.02 & 0.01 & 0.03 & 0.04 & 0.05 & 1 \\
\hline Manganese & $\mathrm{mg} / \mathrm{L}$ & 0.2 & 0.2 & 0.15 & 0.09 & 0.13 & 0.08 & 0.5 \\
\hline Nitrate $\left(\mathrm{NO}_{3}\right)$ & $\mathrm{mg} / \mathrm{L}$ & $\begin{array}{l}0.2 \\
9\end{array}$ & 0.22 & 0.23 & 0.3 & 0.29 & 0.2 & 45 \\
\hline Fluoride & $\mathrm{mg} / \mathrm{L}$ & \begin{tabular}{|l|}
0.4 \\
2 \\
\end{tabular} & 0.4 & 0.45 & 0.4 & 0.4 & 0.4 & 0.5 \\
\hline $\begin{array}{l}\text { Residual } \\
\text { Aluminum }\end{array}$ & $\mathrm{mg} / \mathrm{L}$ & $\begin{array}{l}0.3 \\
4\end{array}$ & 0.3 & 0.32 & 0.36 & 0.34 & 0.38 & 0.2 \\
\hline
\end{tabular}

While analyses results of heavy metals such as Arsenic, Chromium, Lead, Cadmium, Selenium, Mercury, Nickel and Zinc were recorded to be less than 0.001 in all samples which is matching with the requirement of the Egyptian regulations and environmental laws.

Sludge volume index was also carried out for the different samples and results showed relatively small values that indicates the need for a highly efficient sedimentation process for further sludge treatment. The measured values of SVI lays in the range that natural sedimentation by traditional thickening followed by drying process is not expected to result in significant improvement unless an additional coagulant aid is applied [6],[7].

Table -7: Sludge volume index

\begin{tabular}{|l|l|l|l|l|l|l|}
\hline \multirow{2}{*}{ Parameter } & \multicolumn{6}{|l|}{ Result } \\
\cline { 2 - 7 } & 1 & 2 & 3 & 4 & 5 & 6 \\
\hline $\begin{array}{l}\text { Sludge } \\
\text { Volume mg/L }\end{array}$ & 0.19 & 0.27 & 0.083 & 0.11 & 0.14 & 0.09 \\
\hline
\end{tabular}

According to the analyses results, the combined sludge has to be further treated before discharging into water streams in general and the river Nile in particular. In general, it was clear from the results that sludge properties was similar to the properties brought by Chris Binnie [6] and typical values can be expected for raw water from surface water sources.

\section{PROPOSED TREATMENT PROCESS}

Since sludge in water treatment plants is mainly produced from two sources namely the clarifiers sludge and the filter wash water sludge and since the sludge produced from the clarification phases from the different processes did not exceed $3 \%$ of the volume of the total sludge produced, it was recommended to separate the collection of those two different types of sludge to ease the further treatment required specially that the quality of the filter wash water sludge analyses showed much lighter concentration of certain hazardous substances and could be recycled into the plant once more, while the sludge from the clarification step can be treated in a separate line. This separation would lead to reduce the volume and cost of the required additional treatment especially with the limited available areas within the existing water treatment plant.

To reach a better sludge quality that matches the requirement of disposal into water streams, two membrane types were proposed for application in this research. Microfiltration and Ultrafiltration Tubular PVDF membranes were applied in a pilot scale application. Both types of membrane were in tubular structure having twelve internal tubes each of $0.45 \mathrm{~cm}$ diameter and length of 100 $\mathrm{cm}$ with total surface area of $0.18 \mathrm{~m}^{2}$, the membrane material was from Polyvinylidenfluorid (PVDF).

Fig.(2) represents the proposed scheme for sludge management and the proposed treatment system with the application of the membranes to the clarifier sludge only, while Fig.(3) shows the performance of the membrane flux in $\mathrm{L} / \mathrm{m}^{2} / \mathrm{hr}$ along the application period. The membranes were set to operate in dead end mode with minimum power requirement and with an operation cycle of twenty minutes of operation, 10 seconds of back flush as recommended by [7] where a stable flux of $20 \mathrm{~L} / \mathrm{m}^{2} / \mathrm{hr}$ was reached after six hours.

Despite the fact that the total accumulated permeate did not significantly change two modes of pressure were applied. Pressures of one bar and 0.8 bars started with production of an average flux of $90 \mathrm{~L} / \mathrm{m}^{2} / \mathrm{hr}$, and reached the same stable 
flux of $20 \mathrm{~L} / \mathrm{m}^{2} / \mathrm{hr}$ after almost the same duration with more than $97 \%$ recovery from the inlet water volume.

It should be noted that the back wash from the membranes in this research was disposed of. A different scenario for dealing with this water and get the best use out of it should be discussed. M.A.Ashmawy et al.,[7] previously recommended recycling of the wash water of the membranes acting in dead end mode for enhancement of primary sedimentation in waste water treatment plants, which could be also investigated.

It should be noted also that due to the very low values of SVI, membranes are usually recommended as one of the best application for further treatment in general and for solid liquid separation in particular. [7].

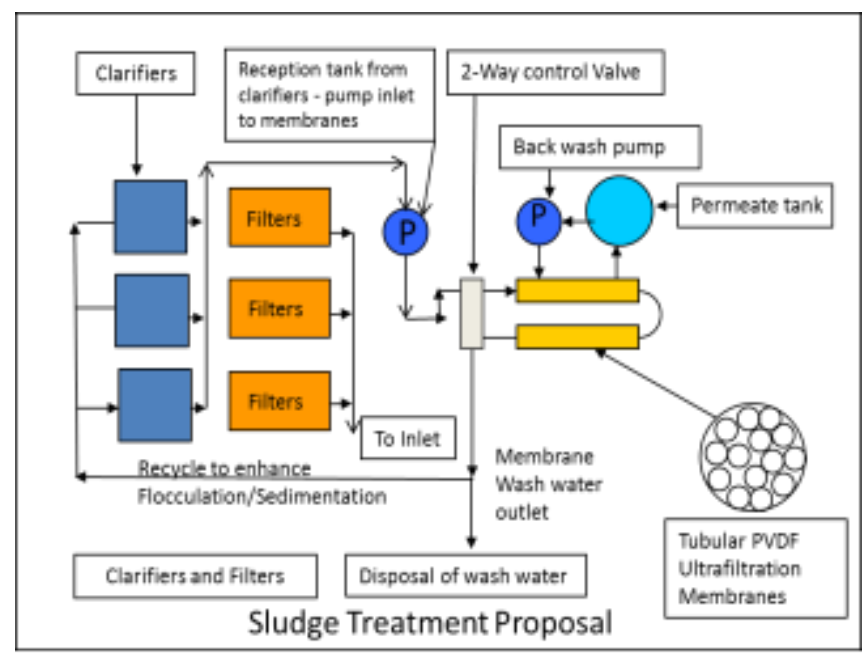

Fig.-2: Existing treatment stages and the proposed sludge treatment

\section{Progress of Flux Production with Time}

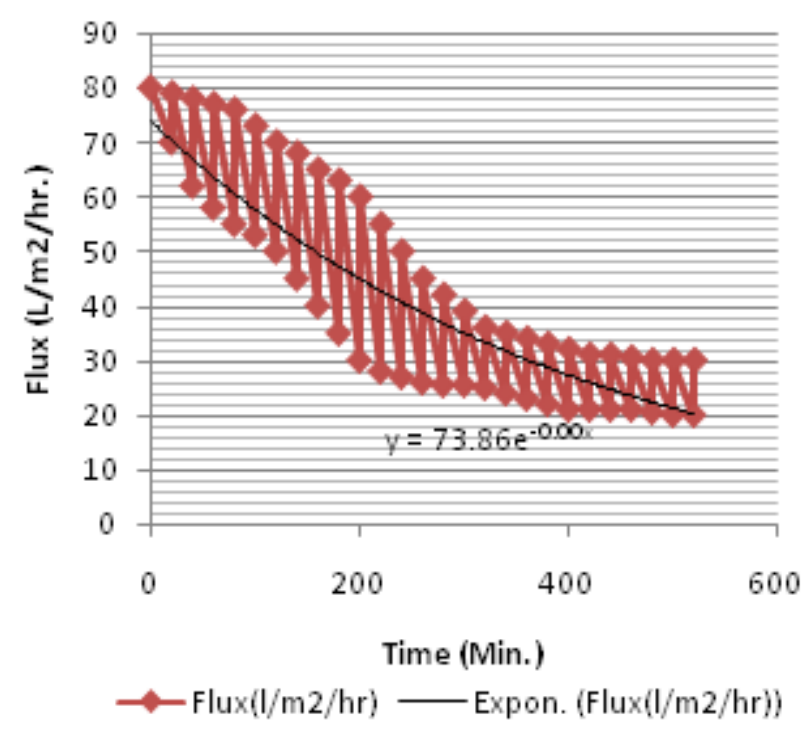

Fig.-3: Application of ultra-filtration membranes for sludge treatment
The effluent quality form both Microfiltration and Ultrafiltration were free from any remaining contaminants and the residual Aluminium was recorded to be less than 0.1 $\mathrm{mg} / \mathrm{l}$.

The advantage of this application was not limited the quality of the effluent but mainly for the very limited area requirement and the minimum operational involvement that will not add additional activities for the operating staff at the existing water treatment plants. Moreover application of membranes in dead mode is considered a power saving mode in comparison with other membrane operation modes which is an additional advantage of the proposed system for use in solving the sludge treatment problem at the existing water treatment plants.

\section{CONCLUSION}

- Water treatment sludge is a diluted liquid with certain hazard contaminations that can't be disposed of to water streams without further treatment.

- Management of sludge recirculation among the treatment plants can significantly reduce the additional area and cost required to reach the allowable quality by the regulating bodies

- In general, results showed that the filter wash sludge are much less in concentration of hazardous parameters and that this water can be easily recirculated within the plant or separately disposed of with no risk on the receiving water body

- It is recommended in all cases to separate the different sources of sludge within the water treatment plant for the ease of treatment and for less area and cost requirements.

- Application of Microfiltration or Ultrafiltration membranes in dead end mode proved high capability in removing the hazardous parameters from water sludge and can be recommended for further treatment of the sludge.

\section{RECOMMENDATIONS AND FUTURE WORK}

- Assessment of the water sludge quality from the different sources of raw water should be carried out before sludge treatment processes is proposed as the produced sludge quality defers significantly in relation to the main raw water source.

- Re use of the concentrate from the sludge treatment should be focused on.

\section{REFERENCES}

[1] Wastes from Water Treatment Plants: Literature Review, Results of an Illinois survey and effects of Alum sludge application to cropland - Illinois Department of Energy \& Natural Resources - 86/2009.

[2] Badr El-Din EzzatHegazy, Hanan Ahmed Fouad and Ahmed Mohammed Hassanain," Incoperation of Water Sludge, Silics Fumes and rise Husk Ash in Break Manufacturing" Advances in Environmental Research,Vol.1, No.1 (2012).PP 83-96 
[3] Hanim Awab, P.T. ThanalechumiParamalinggam and Abdull Rahim Mohd Youssef, Characterization of Alum Sludge for Reuse and Disposal, Malaysian Journal of Fundamental \& Applied Sciences Vol.8, No.4 (2012) PP209-213

[4] Mohammed O. Ramadan, Hanan A. Fouad and Ahmed M. Hassanain , "Reuse of Water Treatment Plant Sludge in Brick Manufacturing" Journal of Applied Sciences Research, Vol.4 No.910), (2008) PP12231229

[5] Sh.A.Rizk, A.A.Mageed and M.H.AbuAli,"Dewatering The Sludge Generated from Water Treatment Plants With Two Hydrocylones in Series" Journal of Engineering Sciences, Assiut University, Vol. 38, No. 3, , May 2010 PP.797-806

[6] Chris Binnie Independent Consultant, Basic Water Treatment, Martin Kimber Atkins Water Publisher, UK - Fifth Edition - 2013.

[7] M.A.Ashmawy, W.Fuchs and I.H.Alhattab, "Assessment of Biological Wastewater Treatment with Application of Membranes", The fourth international conference for low cost waste water treatment, National Centre for Research, Cairo, Egypt, 2003. 